\begin{tabular}{|l|l|l|}
\hline \multicolumn{2}{|c|}{ PublisherInfo } \\
\hline \hline PublisherName & $:$ & BioMed Central \\
\hline \hline PublisherLocation & $:$ & London \\
\hline \hline PublisherImprintName & $:$ & BioMed Central \\
\hline \hline
\end{tabular}

\title{
Polymerase may be key to flu's virulence
}

\begin{tabular}{|l|l|l||}
\hline \multicolumn{2}{|c|}{ ArticleInfo } \\
\hline \hline ArticleID & $:$ & 5046 \\
\hline \hline ArticleDOI & $:$ & $10.1186 /$ gb-spotlight-20051206-01 \\
\hline \hline ArticleCitationID & $:$ & spotlight-20051206-01 \\
\hline \hline ArticleSequenceNumber & $:$ & 109 \\
\hline \hline ArticleCategory & $:$ & Research news \\
\hline ArticleFirstPage & $:$ & 1 \\
\hline \hline ArticleLastPage & $:$ & 3 \\
\hline \hline & & RegistrationDate : 2005-12-6 \\
\hline ArticleHistory & $:$ & OnlineDate \\
\hline \hline ArticleCopyright & $:$ & BioMed Central Ltd2005-12-6 \\
\hline \hline ArticleGrants & $:$ & \\
\hline \hline ArticleContext & $:$ & 130595511 \\
\hline \hline
\end{tabular}


Mutations in the polymerase gene could explain how the influenza virus jumps the species barrier, according to a study in this week's Proceedings of the National Academy of Sciences. The mutations appear to enhance the enzyme's activity, making the virus more virulent. Similar mutations are also present in the highly pathogenic avian flu virus $\mathrm{H} 5 \mathrm{~N} 1$, strains of which have recently been detected in mammals. These findings suggest that changes to polymerase may be a prerequisite for adaptation to a new host, opening the door to a potential pandemic, according to study author Juergen Stech, who headed the team from the Institute of Virology in Marburg, Germany.

"We can conclude from our studies that we have some convergent evolution through the polymerase [gene] -- but it is also clear that the polymerase is not everything," Stech said.

To model the species jump from bird to mammal, the researchers compared two previously existing strains of flu virus. One strain, SC35 - also known as H7N7 -- came from a virus that killed large numbers of seals off the U.S. east coast in the early 1980s, later passaged through chick embryo fibroblasts to become infectious to birds. The other strain, SC3M, was derived from SC35 to infect mice.

The team introduced mutations into individual genes in both strains, to find out what it was that made the viruses more lethal in mice. They noted that mutations to the SC35M polymerase protein PB2 further increased the virulence of the already lethal strain. The changes appeared to enhance polymerase activity, a step correlated with high lethality, according to Stech. The researchers noted that similar mutations have already occurred in highly pathogenic natural flu strains, including H5N1. "We see a parallel convergent evolution of the polymerase changes [with] natural strains, especially H5N1 strains," Stech told The Scientist. Although it's unclear what role these mutations play, the researchers suggest they may help enhance the replication and transcription of the virus.

This is not the only group to pinpoint mutations in polymerase as a potential factor in flu's virulence, said Robert Webster of St. Jude Children's Research Hospital in Memphis, Tennessee. "But it's an oversimplification to say that only mutations in the polymerase gene are required for this adaptation." The only conclusion that can be drawn, said Webster, who was not involved in the study, is that virulence is polygenic, and will depend on both the host and the virus. "Each virus and each host is going to have a different set of changes," he said. "The model itself is a bit contrived," he added, "but even so, I think they're on the right track."

Alan Hay of the National Institute for Medical Research (NIMR) in the UK, who was also not a coauthor, cautioned that it's difficult to extrapolate findings from one virus to another, noting it remains unclear what influence polymerase mutations will have on H5N1. The mutations pinpointed in the current study "probably are more important [to] the adaptation and the virulence in the mouse," he said.

Influenza's past jumps from birds to humans may have been aided by a mammalian intermediate, some researchers suggest -- raising issues about the safety of creating a virus in the laboratory that could potentially cause a new flu pandemic. Yoshihiro Kawaoka, Tokyo University in Japan, however, noted that some H5N1 viruses circulating in the wild are already highly lethal to mice. "So really it doesn't matter," said Kawaoka, who did not participate in the study, "because these naturally occurring viruses are more important than the viruses created in high containment laboratories." 


\section{References}

1. K. Schlatter, "Nature bird flu paper 'wrong,"' The Scientist, July 15, 2005., [http://www.thescientist.com/news/20050715/01]

2. G. Gabriel, "The viral polymerase mediates adaptation of an avian influenza virus to a mammalian host," Proceedings of the National Academy of Sciences," December 5, 2005., [http://www.pnas.org/]

3. Institute for Virology, [http://www.med.uni-marburg.de/e-einrichtungen/virologie/geschichte/]

4. Robert Webster, [http://www.stjude.org/faculty/0,2512,407_2030_3957,00.html]

5. C. Holding, "Flu virulence linked to species jump," The Scientist, February 6, 2004., [http://www.thescientist.com/news/20040206/01]

6. Alan Hay, [http://www.nimr.mrc.ac.uk/virology/hay/]

This PDF file was created after publication. 